\title{
Agriculture as an asset class: reshaping the South African farming sector.
}

\author{
Antoine Ducastel ${ }^{1}$ \& Ward Anseeuw ${ }^{2}$ \\ Paper for the international conference "Finance, Food and Farmland", 25 January 2014. \\ International Institute of Social Studies (ISS) \& Centre for the Study of Transition and \\ Development (CESTRAD) at ISS, The Hague, The Netherlands.
}

\section{Introduction}

According to financial professionals, from institutional investors to "alternative" portfolio managers ${ }^{3}$, agriculture is more and more presented as an emerging asset class (Chen et al., 2013). The arising of such assets is based on fundamental ${ }^{4}$ and financial analyses by investors which all tend to underline the very same driving factors: "Strong long-term macroeconomic fundamentals; attractive historical returns on land investment; a mix of current income and capital appreciation; uncorrelated returns with the equities market and a strong hedge against inflation" (HighQuest Partners, 2010).To take advantage of these different trends, there are various investments' options: commodity future contracts or index funds/exchange traded funds ${ }^{5}$; public or private companies' equities related to agriculture ${ }^{6}$; farmland and agricultural property (Goldberg et al., 2012).

This interest from financial industries in agricultural value chains is not totally new. In the US for instance, it is estimated that institutional investors, especially long term institutional investors such as pension funds or university endowment funds, possessed $27 \%$ of the country's farmland in 2007 (GlobalAgInvest, 2012). However, its spread towards new geographical regions, (Latin America - beyond Brazil and Argentina -, as well as Asia and increasingly in Africa (Land Matrix, 2013)) seems to announce a new wave of agricultural investments. This renewed investor dynamic towards deeper integration of agriculture must be related to "the multiple food-energy-climate-finance crisis" (Margulis, 2013) which, inter

\footnotetext{
${ }^{1}$ CIRAD, UMR Art-Dev \& University of Pretoria, Post-graduate school of agriculture and rural development; antoine.ducastel@cirad.fr.

${ }^{2}$ CIRAD, UMR Art-Dev \& University of Pretoria, Post-graduate school of agriculture and rural development; ward.anseeuw@cirad.fr.

${ }^{3}$ See, inter alia "Farmland: Yield-starved investors go back to the land", Euromoney, January 13, 2014;

${ }^{4}$ Based on macro-economic data (i.e. growing world population, rising incomes in the developing world, etc.)

5 A commodity future contract tracks a specific commodity; an exchange-traded fund track a basket of agricultural commodities (Goldberg et al., 2012)

${ }^{6}$ South Africa's Public Investment Corporation (PIC), which manages the "Government Employees Pension Fund", holds significant positions in the country's bigger agro-food listed companies (Tiger Food, Woolworths, etc.) (Greenberg, 2009); Silverlands fund, a London-based private equity fund owns 30,2\% of Crookes Brothers - a major corporate venture engaged | in primary agricultural production in South and Southern Africa (Crookes Brothers, 2013)
} 
alia, drove a sharp increase of commodity prices and pushed financial investors toward "emergent" and/or physical asset classes.

The African continent tends also to be more and more integrated by financial markets. In fact, since these crises, new narratives and representations are being spread around the African resilience to the financial crisis and the sharp continental projections regarding both economic and demographic growth ${ }^{7}$. As shown by Vallée (2011), this change in perception has been largely fuelled by financial industry actors, such as the McKinsey global Institute or the Emerging Markets Private Equity Association (EMPEA) ${ }^{8}$, through their own surveys and indicators. In the same time, a full range of African financial service providers, from rating agencies to portfolio managers, have been established with the aim to support these expected financial flows. These innovations are not passive responses to the demand from investors looking for opportunities on the continent, but rather emanate from African actors playing an active role mediating demand and offer. As such, they select and structure the African investment offers on one hand, raise and channel the international and/or national demands on the other hand. In addition, they play a key role by converting capital and resources from these two different arenas. Through their actions, these African intermediaries set up the instruments and cognitive frameworks of these "emergent" markets and assets (Bessy and Chauvin, 2013).

In this paper, we will try to understand how an emerging group of South African intermediaries are currently trying to shape, or reshape, farms and others segment of the agricultural value chains as an investment opportunity for institutional investors, i.e. as an asset class. We define an asset as any value recognized as such by financial markets. To get such recognition, a particular good, service or activity must be framed to fit with the financial market requirements and values. An asset is based on specific beliefs, that it can generate a positive cash flow in the future, preferably outperforming the average profits on financial markets, and is liquid enough (Orléans, 1999); and on specific devices, this it can be evaluate and compare to others thanks to standardized benchmarks. This financial valuation (Vatin, 2013 ) is not a natural given but rather produced by particular actors or group of actors in a specific social environment.

Focusing on this emerging sub-financial industry, i.e. the investment funds and companies dedicated to agriculture and agro-industries, we will analyze the concrete strategies and instruments mobilized to "unlock" this financial value 9 . These "pioneers" face a multifaceted mediation as a "financialisation mediator" (Morales and Pezet, 2010) between global investors in one hand, local agricultural sector on the other hand. By analyzing their daily management, their interactions with investors, farmers, workers and government, we aim at understanding the mechanisms of diffusion of "financialisation" (Kadtler \& Sperling, 2002;

\footnotetext{
${ }^{7}$ For instance both Time magazine and The economist have run out covers on "Africa rising"; Time magazine, November 2012 and The economist, December 2011

${ }^{8}$ McKinsey Global Institute, Lions on the move: the progress and potential of African economies, 2012; EMPEA, Global limited partners' survey. Investors' views of private equity in emerging markets, 2013

${ }^{9}$ In its presentation an investment fund specialized in South African agriculture states that "The objective remains to not only | become the most successful food producer in SA, but almost more importantly, the most valued food producer"
} 
Epstein, 2005; Weinstein, 2010; Fine, 2012).This particular financial channel is still newflanged and thus narrow, at the margin within South Africa and Africa's agricultural financing. However, in our view such innovations are an interesting case study for the financialisation debate as an attempt to expand the financial markets' realm.

South Africa has lately seen a significant development of financial vehicles servicing in agriculture, offering a set of market professionals and instruments which suit these innovations (Ducastel et al., 2011). In addition, it is often considered as a stepping stone for Africa in particular through the expansion of its companies in search for new markets (Hall, 2012), so the African scale will sometimes have to be considered.

A last point needs to be clarified: the category of assets we are talking about and the frontier of these categories. In the financial industry, a trend toward a deeper specialization on an asset basis is observable. For instance, in the US financial industry some managers are only servicing in farmland and agricultural property investment or even in a specific crop (Goldberg, 2012). However, our South African sub-field doesn't seem to be structured on such basis, and -in our view - it is still possible to speak about agriculture and agro-industries as a unique asset class, or rather a tangle of assets. Indeed, investments in agricultural commodities, public and private shares or farmland in South Africa seem to be driven by the very same dynamics. In addition, as mentioned before, the financial sub-industry specialized in agriculture is still narrow with intermediaries often offering a full range of services/investments. Unless specified more precisely, when we refer to agricultural asset, it includes the different investment's options (e.g. commodities, equities, and properties).

The paper will start by a general characterization of the financial vehicles servicing in South African agriculture focusing on the interactions between investor(s) and manager. Then, we will detail the production process of an emerging asset class, the South African farms, distinguishing the mitigation of the specific sectorial and national risks and constraints, the production and the management of the information flow and the neutralization's attempts of social "interferences". Finally, the conclusion will try to contribute to the financialisation's academic debate by considering in particular the political dimensions of such process.

\section{Investment funds/companies in South African agriculture and agro-industries: the structuration of new financial channels}

Academics (Daniel, 2012), cooperation agencies (FAO, 2010) and media pay more and more attention on the emergence and development of financial vehicles investing in African agriculture and agro-industries. Such funds raise capital on financial markets and channel it toward investment opportunities which they identified, building progressively an "asset portfolio".

These structures are usually split into various legal entities, sometimes located in different countries, with capital flowing through them. For instance, a funding vehicle established by European or North American investors, might be registered in Mauritius, having its managing 
body in South Africa and investing in all Southern Africa. Because of this multiple positioning and the opacity which often surrounds such activities, investment funds and companies operating in South African agriculture remain a misunderstood phenomenon.

These entities are specialized financial vehicles grouping limited partner(s), the investor(s), and a general partner, the asset manager. In order to better understand these financial vehicles as well as their diversity (from a structural as well as strategy and activity point of view) it is important to detail both investor's and asset management's construction and trajectory as well as the relationships and interactions between these two actors.

On the investors' side, those currently investing in South African agriculture and agroindustries include institutional investors ${ }^{10}$,i.e. public or corporate pension funds (Public investment corporation -South Africa-, the pension fund Pensionskassernes Administration Danemark-), endowment funds (Vanderbilt University endowment), fund of funds, insurance companies (Old mutual, Sanlam) or commercial banks (Rand Merchant Bank). We also found development financial institution (e.g. the African Development Bank, Proparco, the European Investment Bank) but also private foundations (e.g. "Alliance for a Green Revolution in Africa") and Family Office. The source of the capital, mainly related to their liability structures (Aglietta and Rigot, 2009), weighs significantly on the investment policy, and thus on their choice and expectations regarding agriculture. For instance, pension funds are looking for long term and stable return investments to reward their subscribers, while endowment funds focus on a diversification of their asset classes which are not correlated with one another (Campbell, 2011).

These investors differ also in objectives, as development finance institutions try to archive returns for their shareholders and developmental goals in terms of poverty reduction or economic redistribution. Either national (e.g. Norfund from Norway, CDC from UK), regional (e.g. African Development Bank) or multilateral (e.g. International Finance Corporation), they provide "long term finance for private sector enterprises in developing countries" (Daniels, 2012) through a private operator (OXFAM, 2012) and accept smaller financial returns.

These investors entrust their capital to a managing company, which is the implementers of the projects. These companies claim a field experience and a deep network with countries/regions they invest in. Through the valorization of such "indigenous capital", they affirm their essential role as gateway to the country or the region and its agricultural value chains. Indeed, they are at the margin between this indigenous capital on one hand, and a financial capital on the other hand (Dixon, 2012); between "the bush" and the "financial industry". As they handle non-formalized and non-benchmarked assets, a diversity of managing entities compete each other in this structuration process to sell their specific product and capture the investor's flows. As such, although still narrow and still representing an emerging financial sub-

\footnotetext{
${ }^{10}$ An Institutional investors can be defines as "a specialized financial institution collectively managing contractual saving plans for a third with specific risk, performance and maturity goals”; Aglietta and Rigot, 2009
} 
industry, there are several managers operating in the South African agricultural value chains who differ from a project and strategy point of view (Oakland Institute, 2012). Considering their profiles and trajectories, we note companies' staff with different backgrounds and from different areas. Firstly, we identify a group with a previous experience in a development financial institutions involved in Africa (CDC group, FMO, Development Bank of Southern Africa) as investment officers, investment analysts or portfolio managers (e.g. Phatisa). Secondly, another group comes from South African financial industries but with a full range of specialties: insurance, private equity (e.g. Old mutual, PSG group), some of them being specialized Black Economic Empowerment vehicles. Indeed, private equity and venture capital are more and more promoted as an instrument of economic redistribution in the postapartheid South Africa (KPMG \& SAVCA, 2013).Thirdly, these managing companies mobilize an agribusiness expertise to "feed the pipe" of investment's projects. Thereby, they integrate staff from agro food national or international leading firms (e.g. Unilever, Afgri, etc.). According to their staff's career paths, managing companies implement different practices and strategies. They also position themselves on various financial sub-fields and asset class, mobilizing different networks of investors and argumentative registers to convince them; indeed, one would emphasis on the "consumption boom" in Africa, while the other one would stress on food security issues.

An investment fund or company is basically the alliance of these two types of collective actors, the manager and the investor(s), each with their own interests and beliefs. Usually, the manager initiates the fund's project, defines its mandate and then raises capital from potential investors; but a couple of investors, especially DFIs, have also launched a tender for a manager with a specific mandate ${ }^{11}$. The concrete aspects of the investment vehicle, the structure of the fund in one hand, its strategy and practices on the other hand, are then specified through negotiations between the parties and formalized into an investment policy and a shareholders agreement.

Such agreement reflects the balance of power between these actors. Indeed, according to the number, the profile and the size of investors seating on the board, but also to the track records of the manager, the balance of power and the room of manoeuver of the actors change. The alignment of interest and the respect of the investment policy by the manager are major concerns for the investors. Indeed, the trust, which is the legal structure of most of the fund, gives them few control means a posteriori (Montagne, 2006). That's why investors protect themselves through a set of legal and technical mechanisms: manager's financial participation, side letter ${ }^{12}$, external audit, remuneration system by profit sharing ${ }^{13}$, implementation of an advisory committee ${ }^{14}$, framing of the investments by quotas, etc. But investors cannot formalize everything in the fund's legal status and managers often empower

\footnotetext{
${ }^{11}$ e.g. the African Agriculture Fund

12 This is an agreement between the fund manager and an investor that outlines different terms that will apply to this investor's investment into the fund, giving him some flexibility to go outside the terms of fund legal document

${ }^{13}$ The manager's remuneration standards in the private equity industry are usually referred as 2/8/20: $2 \%$ of the asset value under control as management fee; a hurdle internal rate of return fixed at $8 \%$; and $20 \%$ of benefits as profit sharing.

${ }^{14}$ Usually, the first round shareholders and the bigger ones are sat in this committee which supports the management team, ensures the investment thesis and check the budget; but it doesn't participate to the investment decisions.
} 
themselves in the daily practices. For instance, managers usually take advantage from the diversity of investors by arbitraging between their expectations ${ }^{15}$.

Looking at funds and investment companies operating in agriculture and agro-industries in South Africa, a set of relevant aspects can be identified, illustrating the diversity of such vehicles:

- The status of the financial vehicle, which determines the life span of the fund and the asset class focused on. So far, most of the vehicles we identified are private equity or venture capital entities which buy equities in public or private companies ${ }^{16}$ related to agriculture (farms, inputs producers, agricultural financial services' company, etc.). We distinguish private equity fund with a limited life span, from 7 to 12 years in average $^{17}$ (e.g. Futurgrowth Agri fund, Agri-Vie) from holding companies and private investment company which are immortal entities (e.g. AgriGroup). Usually, funds are reserved to professional investors as they know this specific industry and are able to immobilize their capital during the fund life-span. Conversely, a few specialized companies are listed on the Johannesburg Stock Exchange (JSE) with public shareholders (e.g. Zeder ${ }^{18}$ ). Then, some promoters are currently developing a listed vehicle exclusively dedicated to agricultural property, a real estate investment trust; but so far such project has not been fully materialized.

- The "frontier" of the investment company mandate. As an alternative asset, investments into South African value chains are often managed by a specialized manager who builds a full portfolio of this asset class. But sometimes generalist funds or emergent/frontier market funds also invest in this category driven by a diversification strategy (e.g. Abraaj group, Emerging Capital Partner). The geographical mandate is also variable and funds can focus on one country (it is the case of several funds active in South Africa), on one region (Southern Africa), on the entire continent, or on an unclear "frontier market" scale ${ }^{19}$.

- The stage of investment is also varying significantly, as is illustrated by the difference between "brown" or "green" fields" investments or "core" and "conversion" strategies ${ }^{20}$ (Goldberg et al., 2012), indicating the "maturity" of the asset and the set of instruments which will be mobilized ${ }^{21}$. However, because of the actual low competition around South African and African agricultural assets, but also because of the short-term evaluation on asset profitability by investors, managers focus mainly on

\footnotetext{
${ }^{15}$ Expected in one case, all the funds we investigate have several investors from at least two different countries; most of them have both different private investors and development financial institutions as shareholders

${ }^{16}$ With public companies investment funds or companies pursue a private equity over-taking strategy by removing the shares out of the stock exchange (Burch and Lawrence, 2012); it is for instance currently happening with AFGRI which has been acquired by AgriGroupe.

${ }^{17}$ A bit longer than "standard" private equity funds which life spans comprised from 5 to 7 years (Daniels, 2012)

${ }^{18}$ Zeder, a public holding company on the JSE launched in 2006 by leading asset management company PSG, is currently managing four agribusiness portfolios ranging from primary production in Zambia -Chayton- to the seed industry -Agricol(Zeder, 2013)

${ }^{19}$ Such funds rather than plan a strategy on a geographic scale are focused on markets' trends.

20 "A core strategy invests in currently producing agricultural land in highly productive areas", while "A conversion strategy targets non-producing properties or low-yielding land in marginal areas" (Goldberg et al., 2012)

${ }^{21}$ Private equity industry is subdivided between venture capital, growth capital, distressed capital, etc., each ones with its own know-how and technics.
} 
investment already "mature", i.e. a good financial track record, a confirmed management team, a global exposure, a listing on a stock exchange ${ }^{22}$.

- The strategic allocation and the diversification strategies:

- Among asset classes (equities, commodities on Futures market, farmland and agricultural infrastructures);

- Along the value chain (either in one segment -e.g. fertilizers, farms, retailersor with a value chain's approach, with sometimes explicit targets for each segments);

- Among productions and crops. Certain funds have an investment charter emphasizing certain focuses and sectors, or preventing managers to invest in specific sectors such as tobacco or timber (e.g. Agri-Vie). When they invest in primary production, they often balance between "a sheer asset strategy", which is invested in one specific crop (e.g. cash crop) and a "flex crop and commodities" strategy (Borras, 2013) with different crops on the same farm during the year or from a year to another one.

- The land ownership. When they invest in primary production, many investment companies and funds consider farmland as the central component of the investment and land price increase expectations are integrated in their cash flow model. But African and South African farmland can be a risky asset as witnessed by the recent mobilizations around large scale acquisitions in Madagascar (AndrianirinaRatsialonana et al, 2011) or in Mozambique (Oakland Institute, 2011); so others dedicate only to out-growers schemes and/or nucleus estate models without large-scale land acquisitions (e.g. African Agriculture Fund).

- The management of the targeted companies. When they buy equities in private or public agribusiness corporates, funds or holding companies take either a minority or a majority stakes. According to their shareholding, they play a more or less active role in the daily management of the acquired firm. In others words, they can either appoint a new CEO and a management team or just monitor the operations through nonexecutive members on the board company.

- The "impact investment" component. Some funds implement, often on request of the development financial institutions, social and environmental performance standards (e.g. IFC's performance standards) and investment charters -including for instance land policies, or exclusion lists- or join sometimes impact investing networks (e.g. Global Impact Investing Network). In addition, for vehicles funded by the IFC, there exists a "redress and compliance mechanism" for people affected by these investments (i.e. Compliance advisor/ombudsman).To control such developmental dimensions, these investors implement monitoring procedures and managers often to report annually on key indicators (job creation, BEE rating, etc.). For the African Agriculture Fund, the promoters of the fund have developed an independent technical assistance

\footnotetext{
${ }^{22}$ Such «financial bias » in the selection process benefits to the most "financialized" farms and agricultural firms in Africa and South Africa: the African Agriculture Fund purchased the Zambian company Golden Lay in 2012 from the Abraaj Group, another private equity firm; Zeder bought its farms in Zambia through the acquisition of Chayton capital, a private equity fund.
} 
facility which should encourage the integration of small scale farmers and local communities.

Rather than a unique financial channel toward African agriculture, these investment companies and funds are diverse, built around a plurality of the investor/manager relationship. However, they are all engaged in the same production process of a specific asset class. In such process, managers play a key role at the interface of two different arenas.

\section{Toward the production of the asset: from South African farms to financial investors}

As we have defined in the introduction, an asset is any value recognized as such by financial markets. Such financial value relies on an active work of shaping and promoting by intermediaries which aim to attract financial flows. This work can be described as a translation process from a particular good, service or activity inserted in a specific environment to a reliable and sustainable investment for financial markets and actors. For this translation, intermediaries will mobilize a set of techniques and instruments (Lascoumes and Le Galès, 2005). Such production process is embedded in a broader social and political environment. Indeed, the ability to mobilize these instruments relies on specific policies and social structures historically and spatially situated.

South African and African agricultural value chains seem to be currently the object of such a translation attempt. Therefore, the production of an emerging asset class through the specific case study of South African farms will be analyzed focusing on the intermediaries' role. Three different modalities of such translation can be identified for this research, but concomitant to the reality: firstly, intermediaries have to manage the characteristics and constraints surrounding agriculture production to "unlock the value"; secondly, they must build an information flow toward investors which relies on recognized standards and benchmarks; finally, this shaping work is faced with social, political and cultural resistances which managers have to deal with.

\section{A. South African farms as a liquid, profitable and predictable bundle of assets}

To be recognized as an asset, that is a financial value, a good or an activity must be considered as liquid (Orléans, 1999) and generating a predictable positive cash flow by financial markets. (South African) agriculture faces several inherent risks (e.g. natural risks, international markets volatility, etc.) which historically discouraged private investments because of its random returns. So, to attract financial capitals, managers have to build a stable and positive cash flow in one hand and to increase the liquidity of their farms on the other hand.

The mitigation of agricultural risks relies on the mobilization of specific instruments, which are " a set of rules and procedures, more or less coordinated, which govern interactions and behaviors of actors and organizations (...) provide a stable framework of anticipations which 
reduces uncertainties and structures collective actions" (Lascoumès and Le Galès, 2005). For our case, we identified different instruments which seem to play a crucial role in the asset production process in the South African farming sector:

- In 1996, with the Marketing Act, the South African Futures Exchange (SAFEX) is created, i.e. a futures market which substitutes the previous regime's agricultural commodity price regulatory and marketing boards (Vink and Van Rooyen, 2009). Such «market-based price risk management» (Newman, 2009) allows agricultural value chain actors to hedge the sales/purchases of their products, reducing the uncertainty around the price without State interventions. In addition, this futures market creates a centralized and standardized informational flow available to the public. A good example thereof is the system of the silo receipt which guarantees the amount and the grade of the grain delivered. These innovations have led to new actors to engage in the agricultural sector by creating a demand for future trading services in a sector where the "single channel fixed price" model was the norm. These new "market players" have acquired an increasing role in the sector's restructuration until involved themselves in primary production investments.

- These financial flows toward agricultural value chains also benefit from the international and national legislations in favor of free movement of capital (Ashman et $a l ., 2011)$. Indeed, these funds are often split into various entities or special purpose vehicles, registered in offshore financial centers and protected by international laws. Thereby, Mauritius is becoming a hub for investments both in Asia and Africa thanks to an incentive tax policy ${ }^{23}$ and a set of bilateral double taxation agreements ${ }^{24}$.

- Financial flows to (South) African farms are also boosted by the involvement of Development finance institutions, national and international, both at the financial and the technical levels. Firstly, in several funds servicing in South African and African value chains, DFI's are shareholders (e.g. Proparco, FMO, DEG, OPIC, African Bank of development, DBSA, IDC, etc.). They often implement innovative financial mechanisms to leverage private capitals, by accepting a deferred profitability or by promoting specific securing instruments, i.e. the "master contracts of guarantee" 25 from the World Bank's "Multilateral Investment Guarantee Agency" (MIGA) or the "Secondary Fund" 26 implemented by the IFC (Daniels, 2012). Thirdly, they are also active as agricultural and agri-business support services through training sessions or technical assistance facility (e.g. African Agriculture Fund). Fourthly, they play a key role in the promotion and the organization of such financial industries in Africa; for instance the World Bank Group supports the creation and the development of the "Emerging Market Private Equity Association" (EMPEA) and its regional subsidiaries (e.g. Southern Africa Venture Capital Association).

- In the post-apartheid South Africa, investment companies and funds benefit from the structuration of the South African farm market. It is a secured and dynamic market

\footnotetext{
${ }^{23}$ For instance, the Mauritius' regime for global business company ( $\mathrm{GBC} 1$ regime) offers a harmonized corporate and income tax of $15 \%$ and tax free on dividend.

${ }^{24}$ Mauritius and South Africa are bound by a bilateral double taxation agreement signed the $20^{\text {th }}$ July 1996

${ }^{25}$ Specifically dedicated to Private Equity, this master contract is an insurance against political risks in emerging markets

${ }^{26}$ This secondary Fund "provides an exit option for emerging markets limited partner investors" (Daniels, 2012)
} 
based on individual property deeds with a freehold which is constitutionally guaranteed. In addition, water rights for agricultural purposes are also freely exchangeable. Such securitization of land and water rights support a specific conception of the farm as a "bundle of assets" (Capron, 2005) which characterized the firm's design in the financial industry, especially in the private equity industry. The farm is considered here as the sum of independent assets: property deeds, water rights, a "biological asset" -the soil-, and a flow of commodities -grains-. Each asset would be marketable, so managers "unlock" value from these farms through "bundling" and "de-bundling" strategies. For instance, they could either implement mergers and acquisitions between various farms or externalize the real-estate asset by selling and renting back the farmland.

- Then, to mitigate the natural risks (flood, drought), fund managers utilize either multiperil/risk crop insurance or geographical diversification. The insurance ensures the production against all natural risk inherent to the agricultural activity. Geographical diversification relates to the acquisition of farmland in different areas in the country with different agro-ecological characteristics. As for the diversification of the "optimal investment portfolio" theory (MacKenzie, 2006), well known in finance, the objective is to dissolve the specific risk from one asset by a global mitigation in the portfolio based on the complementary between assets and the returning force to the mean (Aglietta and Rigot, 2009).

- They develop "network organizations" (Goldberg et al., 2012) to manage their farms and their other assets. Indeed, they tend to gather either several farms and/or different activities along the value chain, enabling economies of scale as well as facilitating management and risk control. Firstly, input costs (seeds, fertilizers, insurance, etc.) are reduced, since they are sourced centrally and then allocated between the units. Secondly, labour on the farms tends to be both contracted and salaried. The contractor can either be a service provider, paid per task in cash or in kind, or lease the land for an annual rent, becoming the owner of the crop. Such model aims at externalizing the risks of agricultural operations as well as covering the depreciation of the equipment. In this process, the farm's staff, at least the top positions such as the farm managers, can also be hired directly with the objective to get a better control over the operations. A hierarchic salary scale is then established and includes financial bonuses, in cash or as share cropping. These practices transform radically the status of the South African farmers, becoming employees, managers or contractors/service providers.

- Finally, to ensure the efficiency of this centralized management and to reduce the natural risks, such investment funds and companies rely on the utilization of advanced technologies, often imported from other geographical areas or sectors (e.g. Argentina $^{27}$ ): no till farming, precision farming, satellite monitoring, soil analysis and correction, etc.

Managers mobilize a set of devices from different sectors and areas. They largely benefit from the post-apartheid reforms in the agricultural sector (Vink \& Van Rooyen, 2009) and more

\footnotetext{
${ }^{27}$ For the Argentina, see the "pool de siembra" (Guibert \& Sili, 2009)
} 
broadly in the economy (Marais, 2011; Mohamed, 2009). But they are also capitalizing on technical, managerial and financial instruments and know-hows coming from the private equity industry (Champenois, 2011). By combining these different instruments, they tend to create a predictable and fluid environment suitable for the involvement of the financial investors. As Chen et al., claim about US, "Farmland was a value due in part to farm policies, technology, crop insurance as well as commodity prices, and macroeconomic measures". The value of South African farmland, from a financial perspective, derives from this specific "agencement" (Callon et al., 2007).

\section{B. The production of the information flow: farms as a standardized and benchmarked asset}

A financial asset is also a set of standardized benchmarks with key indicators on its "historical" returns, on its variance and covariance (the beta) or on the market risk premium. Such benchmarks allow institutional investors to compare and evaluate their profitability and their complementarity in their portfolio. This "commensuration", i.e. "the translation of different qualities into a common metric that can support, for instance, decision-making" (Styhre, 2013), is a central part of the managers' work to attract financial capitals. In our case, managers apply the standards of financial analysis on South African agriculture from the specific "agencement" we described before.

These benchmarks and calculations are borrowed from the corporate finance analysis and aim at modeling a specific investment on the medium/long term through a cash flow. This accounting framework introduces the value of time in the valuation of transactions and assets (Chiapello, 2005). The production of this information flow is a central part of the fund managers' role and success as they endeavor to translate a specific environment/investment into "global financial language". Indeed, the managers' skills and dexterity to deal with these models and implement it toward new activity areas are central issues in their competition to channel capital flow from institutional investors. Once validated by the investor(s), they guide the managers' action and constitute the benchmarks of their evaluation.

This modeling is largely based on the Discounted Cash Flow (DCF) model which actualizes in present value an investment cash flow on a discounted period (Dufumier, 1996). This financial evaluation is realized before any investment, and re-actualized regularly during the project's life-span. It is used as support both to the decision by the manager/investor whether the investment is profitable and to the evaluation criteria by investors in the asset markets. It is a representation device of the productive world as well as a control device (L'Italien et al., 2011)

This DCF model is built on a set of assumptions regarding the discounted period which include macro-economic projections (i.e. inflation rate, interest rate, taxes) and market data (i.e. price of commodities and inputs). Indeed, such actualization of a farm's assets is down either according the market value, when such value is available (e.g. agricultural commodities), either through an actualization of future income streams (Chiapello, 2005). The 
"present value discount rate" is used to discount or actualize a future cash flow in present value. Such rates are built on market conventions regarding the future; but it is also specific to each fund or company as it corresponds to a particular vision of the environment. Indeed, it takes in consideration the political risk of a specific market. With this model, managers diffuse a new valuation of risk, between macro-economic and financial parameters, which differs, between others, from row macro-economic indicators (Vallée, 2011). In addition, by valuating farms as a sum of assets, such financial instrument supports the specific design of corporate as a "bundle of assets". However, DCF engineers face different challenges according to the asset class they try to model.

The utilization of the DCF model is not new in agricultural primary production, particularly for the cash/grain crop sectors, of which the characteristics fit well with this modeling. Firstly because the seasonality of such agricultural productions give a predictable character to the operations/schedule (planting, fertilizing, spraying, harvest) and, therefore, the costs (seeds, fertilizers, irrigation, labour). Secondly, there are futures contracts on such agricultural commodities and so the selling prices can be planned and guaranteed. For these specific crops, the "translation" work has not been too complex, which could explain why cash crops remain the main target for the financial investors. Today, fund managers in the South African agricultural sector seem to look for a broader application of such calculation in order to attract investors to other agricultural productions. For instance, several are currently applying this framework to cattle production, implemented by themselves or through agencies' consultancy. But so far the valuation of cattle remains on productivity per capita or per hectare without any possibility to build a dynamic cash flow model which constitutes a limit to drain financial capital ${ }^{28}$.

Finally, this DCF model reflects also the relationship between managers and investors as it is produced through intense negotiations (Boussard, 2013). On one hand, the discount rate is built in a competitive environment where managers try to attract institutional investors who are looking for specific financial products (i.e. risk/return profiles, covariance, etc.) and specific benchmarks. For instance, in some cases, foreign investors impose to express these calculations in their specific currency (e.g. dollar). Sometimes, they request other market references for the DCF calculation, e.g. the Chicago Board of Trade grain prices rather than the SAFEX prices. On the other hand, managers are directly interested by such internal ratios as their evaluation and their remuneration are based on it.

As noted, this standard modeling is primarily used by investors to arbitrate between different investment opportunities, in agricultural value chains but also between different asset classes. Managers specializing in South African agriculture participate actively to the double movement of deepening the financial market, by the inclusion of "hybrid goods" (Aglietta and Rigot, 2009) as new asset classes, and connecting the different national markets, by the production and diffusion of worldwide recognized benchmarks (Vallée, 2011).

\footnotetext{
${ }^{28}$ Interview realized in the framework of this research, May 2013
} 


\section{Beyond modeling: "neutralization" and "de-politization" of the asset}

A financial asset is structured on a standard flow of modeling and calculation. But to unlock the financial value, asset promoters have also "to conform" the social reality to these flows. Indeed, managers undertake a "neutralization", or a "de-politization", of the farms in order to fit it into the "bundle of assets" conception. Such work is particularly visible when they have to deal with social or political issues surrounding their farms as they often have to face actors or group of actors who embody and defend other, often incompatible, conceptions of the farmland value. It produces sometimes a distortion and a diversion of their approach and can interfere with the managers' relationships with the investors. Such confrontation sheds light on the political dimension of the production of an asset and how the "ferryman" (Morales and Pezet, 2010) manager turns into a political entrepreneur.

Beside other, a concrete example from the field is the case of occupiers on the farms. During the apartheid era, farm workers, particularly in the Mpumalanga and KwaZulu-Natal provinces were allowed to live on the farm they worked on as "labour tenants". In 1997, the Extension of Security of Tenure $\mathrm{Act}^{29}$ conferred formal residential rights to these (former) workers and their families. This act includes a set of rights and duties for these "occupiers" and for the owners (e.g. security of tenure, access to service, no commercial use of the land, an income under the prescribed amount of R5000) but leaving a margin of maneuver to the two parts to negotiate and organize their daily cohabitation (Sibanda and Turner, 1999).

One of the funds investigated acquired several farms with occupiers ${ }^{30}$. Gradually, such cohabitation generated tensions between the new farm owners and the occupiers ${ }^{31}$. The question of occupiers progressively interferes between the American investor and the South African manager in the fund. Indeed, the investor was more and more anxious about this concern, seen as a potential source of mobilizations and contestations either from the occupiers themselves or from national (e.g. Nkuzi Development Agency) and international coalitions (e.g. Via Campesina, Oakland Institute) focusing on this topic ${ }^{32}$.

The fund manager tried to implement different strategies to "clean" what he considered to be its best asset". They started by realizing an identification/registration of all the occupiers and their family on the farms and introduced a code of conduct which all occupiers should sign. They also implemented a "livestock permit" to register the different owners and a three steps warning system in case of abused from the occupiers. Then, they proposed to remove all occupiers to another piece of land, outside the farm, with official property titles. But occupiers refused such proposition arguing that this land was far away from services and useless for grazing. Then, facing the increasing concerns from the investor, the manager proposes to

\footnotetext{
${ }^{29}$ RSA (Republic of South Africa). Extension of Security of Tenure Act 62 of 1997. Pretoria. Government Printers.

${ }^{30}$ Most of the farmers in the eastern part of South Africa have to deal with these occupiers' issues.

31 These occupiers own cattle who graze on the farm and managers accused them to put them on their grazing land, threatening their cattle by disease contamination. Then, the access to their family graves, situated outside of their area, became also a tension source when the manager trying to control and regulate this access.

${ }^{32}$ This concern regarding investors' reputational risk was particularly strong after one of the investors in Southern African agriculture, Vanderbilt university endowment, was targeted by an activist campaign against land grab (Oakland institute, 2012)
} 
group these farms and to list it as property fund on the Johannesburg Stock Exchange. They argue that in such a case, the international investor would become one shareholder among others of a listed fund. Such strategy aims to dissolve the individual responsibility of the investor into the collective ownership of the market ${ }^{33}$. Regarding the manager's perspective, it allows him to keep the control over the operation on one hand, and to balance the investor's power on the other hand. Such proposition was reject by the investor by virtue of its asset allocation strategy, so finally the manager had to sell these farms.

This example illustrates some of the difficulties faced in the translation process between an international investor and a local manager, and misunderstandings that may arise. While the manager attempts to valorize its indigenous capital to minimize such issue, investor seems more concerned by reputational risk, especially in its home country. Such a gap reflects the different positioning of these actors and gives a concrete example of the intermediation's difficulties.

Secondly, through the implementation of various initiatives and policies to regulate the presence of occupiers on farmland (e.g. code of conduct, livestock permit), fund manager tend to become a political entrepreneur. In fact, to "unlock the value" of agricultural asset they have to mitigate the political and the social issues surrounding farmland and agriculture in South Africa. Indeed, they push for a "disembeddedness" (Polanyi, 1983) of their farms to materialize the "bundle of assets" conception. Paradoxically, even if they claim a purely financial approach through the "asset-fiction", they find themselves engaged in particular forms of "cross-regulation" (Bessy and Chauvin, 2013) alongside other public and private actors.

\section{Conclusion}

Even if African/South African agriculture still represents a minor asset class, investment funds and companies focusing on them are diverse. Their structures, their portfolio and their strategies vary. This paper explained this diversity by focusing on the specific interactions and balances of power between investors and manager portfolios

Such innovations are spatially and historically situated. Indeed, theses financial vehicles mobilized specific institutions and instruments at the national (e.g. tittle deeds, water rights) and international (e.g. bilateral double taxation agreements) levels, and from financial industries (e.g. "bundle of assets" conception). From this specific configuration, or "agencement" (Callon et al., 2007), managers are able to implement financial analysis tools to produce a standardized informational flow. By producing these recognized benchmarks, managers allow institutional investors to evaluate these agricultural assets and potentially integrate it in their portfolios. But these benchmarks are not enough to produce an asset and managers also try to "neutralize" the political and social issues related to agriculture and

\footnotetext{
${ }^{33}$ Thereby, the financial markets' notion of "public" challenges the notion of "public good" as a use by those who live or work on it.
} 
farmland in South Africa by "extracting" the farms from their social fabric. Even if they claim a purely financial and corporate approach, they find themselves engaged as political entrepreneurs.

By considering financialisation through the production of a new asset class in the South African agriculture and agro-industries, we are able to shed light on a number of financialisation process characteristics:

- Firstly, financialisation is a mediation or translation process which often relies on mediation chains. For instance, the development of South African investments funds and companies into local agricultural value chains seems to be partly a stepping stone toward the rest of the continent. Such intermediaries take advantage from their interstitial position. Indeed, by becoming "brokers in financialisation" (Bierschenk, 2000) they get resources and legitimacy in their specific fields ${ }^{34}$. However, we have also seen a "bottom-up financialisation", as it is not a one way process but rather the product of daily interactions and negotiations between actors with diverse interests and values, which take place inside specific institutions or organizations (Kadtler and Sperling, 2002).

- Through this mediation, investment funds and companies import techniques, instruments as well as narratives and representations from others cultural, professional or geographical arenas (e.g. DCF model, no-till farming, "bundle of assets" conception of the firm etc.).

- The financialization process is largely supported by both State(s) and multilateral institutions involvement, especially through a specific kind of parastatal organizations, the financial development institutions. Firstly, such innovations are broadly sustained by specific policies and instruments (i.e. SAFEX, international treaties, MIGA etc.) which increase the financial value of African agricultural assets. Secondly, there is an important transfer of employees and managers between public development institutions and private funds which create a private-public network. Thirdly, through DFI investments as well as public pension funds (Greenberg, 2010) or sovereign funds (Cotula, 2012), there is a substantial public flow fueling such dynamic. Public development support takes on multiple forms but all converge toward the promotion of an African agriculture asset class and its inscription on the developmental agenda.

- Financialization processes also produce abstractions and categories. For instance, an asset tends to reduce a good, a service or any other human or natural activities to financial parameters and transform a farm as a "bundle of assets", becoming a "fictitious commodity" (Polanyi, 1983) or a "fictive capital" (Jessop, 2007). The "brokers in financialisation" are also engaged in boundaries' drawing. As for the "emerging market" for instance, they try to create their own asset class, or category, which matches with their position in the financial industries. South African agriculture and agro-industries are still fuzzy asset categories in structuration and from one

\footnotetext{
${ }^{34}$ Many former white «commercial farmers » in South Africa hit by the land reform programs or the post-apartheid concentration process (Vink \& Van Rooyen, 2009) have benefited from the development of these specialized funds and companies becoming agricultural managers or consultants for them.
} 
intermediary to another such categories cover different goods, services, properties or activities.

- Financialisation implies a valuation process. Indeed, an asset is a particular value. As we have seen such valuation must be understood as an evaluation and a valorization (Vatin, 2013) which rely on standardized benchmarks recognized by the financial markets. This commensuration (Styhre, 2013), i.e. the translation in a common metric, is a support for the decision-making but this is especially a comparison tool as an asset acquires a value only compared to others.

- Finally, we raised the political dimensions of such financialisation process at different levels (Linhardt and Muniesa, 2011). Firstly, with its particular abstractions, for instance the asset-fiction, financialisation tends to produce an alternative representation of the social reality through its "representative devices of the productive work" (L'Italien, 2011), i.e. standard, benchmark, category or modeling. The financialisation's spokesmen, the intermediaries, tend to diffuse such narratives and instruments which are progressively take in by other actors from other fields. Secondly, in some situations asset managers raise tensions in their attempts to produce an asset and impose their specific and exclusive conception of value. In such case, as with the occupiers, they clearly become political entrepreneurs, implementing "corporate policies" or collaborating and negotiating with different actors in order to protect, or increase, the asset value. Thirdly, by channeling and allocating this capital flow toward specific projects, they push and legitimize a specific form and conception of agriculture and food production, and therefore specific actors, to the detriment of others (Ortiz, 2008). Indeed, we note new alliances between these investment companies and funds on one hand and the leading South African agribusiness actors (e.g. Afgri with AgriGroupe or Crookes Brothers with Silverland) for their expansions to Africa. Such alliance will probably tend to reinforce their domination (Greenberg, 2009) and further the small scale agriculture's marginalization in the continent.

Since South African agriculture as a financial asset is relatively new-fangled, more time is needed to better understand the implications of its development. So far, we have seen that the translation process is not a long quiet river with several funds practicing in dire straits with many of their activities not being profitable or even collapsing, particularly in other, less wellestablished African countries (Anseeuw and Boche, 2012). Others are adapting, implementing innovative schemes aiming at considering up- and downstream opportunities and constraints.

The attempts to integrate African and South African farms in the financial markets as an asset class illustrate the cognitive and political work asset categories undergo. However, in this specific case such works are probably more visible because of the political and social conceptions and representations around farmland in South Africa. Polanyi (1983) had already shed light on the "land-commodity fiction" which was an attempt to subordinate land to the industrial society needs. However, he underlined "society's self-protection" movement which curbed such dynamic. Today, is this "land-asset fiction" fully materializing through the subordination of farmland to the financial society needs? 


\section{Bibliography}

Aglietta, Michel, and Rigot, Sandra. Crise et rénovation de la finance. Odile Jacob, 2009.

Anseeuw, Ward, Alden Wily, Lizzy, Cotula, Lorenzo and Taylor, Mike. "Land Rights and the Rush for Land: Findings of the Global Commercial Pressures on Land Research Project". ILC, 2012.

Anseeuw, Ward and Boche, Mathieu. Large-scale land acquisitions in Southern Africa. Current state and investment models implemented. SACAU research report, 2012

Andrianirina Ratsialonana, Rivo, Ramarojohn, Landry, Burnod, Perrine and Teyssier, André. "After Daewoo? Current Status and Perspective of Large-Land Scale Acquisitions in Madagascar", Rome: Observatoire du Foncier à Madagascar, CIRAD, ILC, 2011.

Ashman, Sam, Fine, Ben and Newman, Susan. « Amnesty International? The Nature, Scale and Impact of Capital Flight from South Africa ». Journal of Southern African Studies 37, $\mathrm{n}^{\mathrm{o}} 1$, 2011.

Bessy, Christian, and Chauvin, Piere-M. The power of market intermediaries: From information to valuation processes. Valuation studies Vol. 1 (1), 2013

Bierschenk, Thomas, Chauveau, Jean-Pierre, and Olivier de Sardan, Jean-Pierre. Courtiers en développement. Les villages africains en quête de projets. Khartala, APAD, 2000.

Boussard, Valérie. «Qui crée la création de valeur $\square$ ? » La nouvelle revue du travail $\mathrm{n}^{0}$ 3, 2013.

Callon, Michel, Millo, Yval, and Muniesa, Fabian. Market Devices. Wiley-Blackwell, 2007.

Campbell, John. Investing and Spending: The Twin Challenges of University Endowment Management. Forum Futures, 2012

Capron, Michel. Les normes comptables internationales: instruments du capitalisme financier. Entreprises \& sociétés. La Découverte, 2005.

Champenois, Claire. «Stabilité et transformation des règles. L'évaluation des firmes de biotechnologie par les investisseurs en capital-risque allemand. » In Vie et mort des institutions marchandes, Francois, Pierre. Les Presses de Sciences Po, 2011.

Chen, Songjiao, Wilson, William W., Larsen, Ryan, and Dahl, Bruce. Investing in Agriculture as an Asset Class. Agribusiness and Applied Economics Report 711, Department of Agribusiness \& Applied Economics, North Dakota State University, 2013

Chiapello, Eve. «Transformations des conventions comptables, transformation de la représentation de l'entreprise ». In Les normes comptables internationales. Instruments du capitalisme financier. Capron, Michel. Entreprises \& sociétés. La Découverte, 2005.

Cotula, Lorenzo. The international political economy of the global land rush: A critical appraisal of trends, scale, geography and drivers. The journal of peasant studies, Vol. 39, N³-4, 2012.

Daniel, Shepard. «Situating private equity capital in the land grab debate ». Journal of Peasant Studies 39, n ${ }^{\circ}$ 3-4, 2012.

Davis, Graham. Farmland as an Asset Class: The Focus of Private Equity Firms in Africa. 2011

Dixon, Marion. "The corporate standard and the reproduction of dominant class in Egypt». Conference global land grabbing II, Land deal politics initiative, 2012.

Dufumier, Marc. Les projets de développement agricole : Manuel d'expertise. Khartala, 1996

EMPEA, Global limited partners survey. Investors' views of private equity in emerging markets, 2013

FAO. Agricultural investment funds in developing countries, 2010.

Fine, Ben. «La financiarisation en perspective ». Actuel Marx 51, $\mathrm{n}^{\circ}$ 1, 2012. 
GlobalAgInvest. Farmland: an untapped asset class? Quantifying the opportunity to invest in agriculture, 2012.

Goldberg, Ray, Segel, Arthur I, Herrero, Gustavo, and Terris, Andrew. "Farmland Investing: A

Technical Note." Harvard Business School Background Note 211-022, 2012.

Greenberg, Stephen. Contesting the food system in South Africa: issues and opportunities. Research report. PLAAS, 2010.

Hall, Ruth. "The next Great Trek? South African commercial farmers move north". Journal of Peasant Studies 39(3-4), 2012.

HighQuest Partners. Private Financial Sector Investment in Farmland and Agricultural Infrastructure". OECD Food, Agriculture and Fisheries Papers, No. 33, OECD Publishing, 2010.

Jessop, Bob. Knowledge as a fictitious commodity:insights and limits of a Polanyian perspective. In Bugra, Ayse \& Agartan, Kaan Reading Karl Polanyi for the twenty-first century : market economy as political project. Palgrave Macmillan, 2007.

Kadtler, Jurgen, and Sperling, Hans Joachim. «After globalisation and financialisation $\square: \operatorname{logics}$ of bargaining in the german automotive industry ». Competition \& Change 6, n 2, 2002.

Krippner, Greta R. «The Financialization of the American Economy ». Socio-Economic Review 3, $\mathrm{n}^{\mathrm{o}} 2,2005$.

KPMG \& SAVCA. Venture capital and private equity industry performance survey of South Africa covering the 2012 calendar year, 2013

Land Matrix, http://landportal.info/landmatrix/get-the-picture, 2013

Lascoumes, Pierre, and Le Galès, Patrick. Gouverner par les instruments. Les Presses de Sciences Po, 2005.

Linhardt, Dominique, and Muniesa, Fabian. «Tenir lieu de politique ». Politix 95, n 3, 2011.

L'Italien, François, Hanin, Frederic, Duhaime, Eric, and Pineault, Eric. « La financiarisation du secteur forestier $\square$ : le cas de Produits Forestiers Résolu ». Revue Interventions économiques. Papers in Political Economy n ${ }^{\circ}$ 44, 2011.

MacKenzie, Donald A. An Engine, Not a Camera: How Financial Models Shape Markets. MIT Press, 2006.

MacKinsey Global Institute, Lions on the move: the progress and potential of African economies, 2012

Marais, Hein. South Africa Pushed to the Limit: The Political Economy of Change. New York: Zed, 2011.

Margulis, Matias E., McKeon, Nora, and Borras Jr., Saturnino M. «Land grabbing and global governance: critical perspectives ». Globalizations 10, $\mathrm{n}^{\mathrm{0}} 1,2013$.

Mohamed, Seeraj. Financialization, the minerals energy complex and South African labor. Global Labour University Conference, Tata Institute for Social Sciences Mumbai, India. 22-24 February 2009.

Montagne, Sabine. Les fonds de pension entre protection sociale et spéculation financière. Editions Odile Jacob, 2006.

Oakland institute. Betting on World Agriculture: US Private Equity Managers Eye Agricultural Returns, 2012. http://www.oaklandinstitute.org/betting-world-agriculture-us-private-equitymanagers-eye-agricultural-returns.

Orléan, André. Le Pouvoir de La Finance. Odile Jacob, 1999.

Ortiz, Horacio. Anthropologie politique de la finance contemporaine $\square$ : évaluer, investir, innover, PHD, 2008.

OXFAM. Risky business. Intermediary lending and development finance, 2012.

Pezet, Anne, and Morales, Jérémy. «Les contrôleurs de gestion, « $\square$ médiateurs $\square$ » de la financiarisation. »Comptabilité Contrôle Audit 16, $\mathrm{n}^{\mathrm{O}}$ 1, 2010. 
Polanyi, Karl. La Grande transformation: Aux origines politiques et économiques de notre temps. Gallimard, 1983.

Reynaud, Bénédicte, Heilbron, Johan and Bourdieu. Jérôme «Les structures sociales de la finance ». Actes de la recherche en sciences sociales 146, $\mathrm{n}^{\circ}$ 1, 2003.

Sibanda, Sipho, Turner, Stephen. Land tenure reform and rural livelihoods in southern Africa. Overseas Development Institute. Natural resource perspectives n 39, 1999.

Styhre, Alexander. The economic valuation and commensuration of cultural ressources : Financing and monitoring the swedish culture sector. Valutation studies Vol.1 (1), 2013.

Vallée, Olivier. «L'économie africaine saisie par la finance ». Politique africaine $\mathrm{n}^{\mathrm{o}}$ 124, 2011.

Vatin, Francois. «Valuation as evaluating and valorizing ». Valuation Studies, Vol. 1 (1), 2013.

Vink, Nick, and Van Rooyen, Johan. Perspectives on the performance of agriculture in SA since 1994 and implications for its role in archieving sustainable food policy. Working draft paper. University of Pretoria, 2009

Weinstein, Olivier. Pouvoir, finance et connaissance: La transformation de l'entreprise capitaliste entre XXe et XXIe siècle. Editions La Découverte, 2010. 